\title{
Roles of exogenous nitric oxide in regulating ionic equilibrium and moderating oxidative stress in cotton seedlings during salt stress
}

\author{
S. Liu, Y.J. Dong*, L.L. Xu, J. Kong, X.Y. Bai \\ College of Resources and Environment, Shandong Agricultural University, 271018 Taian, P.R.China. "Corresponding author: \\ yuanjiedong@163.com
}

\begin{abstract}
Using a potted experiment, we studied the effect of slow-release nitric oxide (NO) on the physiological characteristics of cotton seedlings subjected to salt stress $(585 \mathrm{mg} / \mathrm{kg} \mathrm{NaCl})$. Sodium nitroprusside (SNP, an NO donor, $2.62 \mathrm{mg}$ ) was applied either directly to the soil, via slow release methods (slow-release bags, slow-release capsules, or slowrelease particles), or via foliar application. $\mathrm{NaCl}$ decreased plant weight and chlorophyll content and increased electrolyte leakage and the contents of proline, ascorbic acid (ASA), and $\mathrm{Na} . \mathrm{NaCl}$ also induced oxidative stress, as indicated by elevated levels of lipid peroxidation and ROS production. Foliar spray of SNP $(0.09 \mathrm{mM})$ enhanced plant growth, promoted ion absorption and transport, and increased enzyme activity. Slow-released NO increased the levels of chlorophyll, ASA, and proline; promoted the uptake of $\mathrm{K}, \mathrm{Ca}$ and $\mathrm{Mg}$; and decreased $\mathrm{Na}$. Moreover, increases in SOD and CAT activity were demonstrated to counter oxidative stress. However, different methods of SNP application have different effects on salt-tolerance. Foliar application was optimal. Slow-release NO, especially slow-release particles, was better able to alleviate $\mathrm{NaCl}$ toxicity compared with direct application of $\mathrm{NO}$ to the soil.
\end{abstract}

Keywords: Cotton, ionic equilibrium, $\mathrm{NaCl}$, oxidative stress, slow-release $\mathrm{NO}$

Abbreviations: ASA, ascorbic acid; CAT, catalase; CRF, controlled release fertilizer; $\mathrm{H}_{2} \mathrm{O}_{2}$, hydrogen peroxide; LRWC, leaf relative water content; MDA, malondialdehyde; NO, nitric oxide; POD, peroxidase; PBS, phosphate buffered saline; ROS, reactive oxygen species; SNP, sodium nitroprusside; SOD, superoxide dismutase; TCA, trichloroacetic acid

\section{Introduction}

$\mathrm{Na}^{+}$in saline soils is toxic to plants and exerts adverse effects on $\mathrm{K}$ nutrition, enzyme activity, and metabolism. Several mechanisms function cooperatively to prevent the accumulation of $\mathrm{Na}^{+}$in the cytoplasm, including active $\mathrm{Na}^{+}$efflux, restriction of $\mathrm{Na}^{+}$influx, and compartmentalization of $\mathrm{Na}^{+}$in the vacuole (Shi et al., 2000). These changes lead to osmotic and ion-specific effects as well as imbalances in plant nutrition, which may involve deficiencies in several nutrients, such as $\mathrm{K}, \mathrm{Ca}$, and $\mathrm{Mg}$ (Qadir et al., 2006). To mitigate and repair the damage, plant cells perform detoxification via the synchronous action of various antioxidants composed of non-enzymatic and enzymatic components. Enzymatic antioxidants 
include superoxide dismutase (SOD), peroxidase (POD), catalase (CAT), and ascorbate peroxidase (APX), whereas non-enzymatic antioxidants include water-soluble components, such as soluble sugar, and lipid-soluble components, such as ascorbic acid (ASA) and protein (Sheetal et al., 2012). Thus, compatible solutes and antioxidants may constitute a strategy for enhancing salt tolerance in plants.

Nitric oxide (NO) is a small, highly diffusible gas and a ubiquitous bioactive molecule. Its chemical properties make $\mathrm{NO}$ a versatile signaling molecule that functions through interactions with cellular targets via either redox or additive chemistry. In recent years, increasing evidence has indicated that NO is involved many physiological processes of plants, such as germination (Beligni and Lamattina, 2000), mitochondrial functionality (Zottini et al., 2002) and enzymatic activity (Zeng et al., 2011). Taken together, these reports reveal the importance of exogenous $\mathrm{NO}$ in the protection against deleterious effects and suggest that one of the mechanisms of NO is to help plants resist stress. First, NO might be involved in increasing the antioxidant content and antioxidant enzyme activity to scavenge reactive oxygen species (ROS). Second, NO might increase excess $\mathrm{Na}$ accumulation in root cell walls and decrease its accumulation in the soluble cellular fraction of the leaves. Lastly, NO could function as a signaling molecule in the cascade of events leading to changes in gene expression under risk element stress (Procházková et al., 2012; Xiong et al., 2010). Moreover, previous evidence indicates that sodium nitroprusside (SNP) was reversed by the addition of an NO scavenger, 2-(4-carboxy-2-phenyl)-4,4,5,5tetramethyl-imidazoline-1-oxyl-3-oxide (c-PTIO), suggesting that the ameliorating effect of SNP is due to release of NO (Srivastava et al., 2012). In our previous study, we added exogenous SNP to controlled release fertilizer (CRF) during the process of CRF production. The application of this mixture to the roots of peanut plants had beneficial effects during iron-deficiency stress (Zhang et al., 2012). However, it remains unclear whether slow-release NO can alleviate salt stress. Based on the known chemical properties of SNP, we choose the SNP as an NO donor and examined the ability of slow-release NO to alleviate salt stress in cotton.

Cotton is an important industrial crop and is a source of fiber. However, the susceptibility of cotton seedlings to salt stress is a major factor in reduced growth and productivity. Information on the tolerance of cotton seedlings to salinity is lacking. Therefore, enhancing the salinity tolerance of cotton by some means would be an important strategy for improving the productivity of this crop.

The potential for exogenous $\mathrm{NO}$ to alleviate $\mathrm{NaCl}$ toxicity in plants has mainly been studied via hydroponic experiments. Studies utilizing exogenous NO to explore $\mathrm{NaCl}$ toxicity in cotton grown on $\mathrm{NaCl}$-contaminated soil are limited. In the present work, we utilized several new approaches to supply $\mathrm{NO}$ to cotton grown in $\mathrm{NaCl}$ contaminated soil. SNP was either applied directly to the soil, via slow release methods (slow-release bag, slow-release capsule, or slow-release particle), or via foliar application. The overall objectives of the present study were to investigate whether slow-release $\mathrm{NO}$ can increase salt tolerance in cotton seedlings and to select a better means of alleviating salt toxicity in cotton seedlings.

\section{Materials and Methods}

\subsection{Plant materials and treatments}

A pot experiment was conducted using saline soil. The soil type was brown soil with the following properties: total nitrogen $(\mathrm{N}), 0.59 \mathrm{~g} \mathrm{~kg}^{-1}$; Olsen phosphorus $(\mathrm{P})$, $55.06 \mathrm{mg} \mathrm{kg}^{-1}$; available potassium $(\mathrm{K}), 78.64 \mathrm{mg} \mathrm{kg}^{-1}$; and $\mathrm{pH}\left(\mathrm{H}_{2} \mathrm{O}\right) 7.79$. The salt-stressed environment was created by adding $585 \mathrm{mg}$ of $\mathrm{NaCl}$ to $1 \mathrm{~kg}$ of soil.

Cotton (Gossypium hirsutum L.) seeds were seeded on May 15, 2012. The plants were grown in plastic pots (four plants per pot) with a capacity of $2.5 \mathrm{~kg}$ of air-dried soil. The pots were arranged in a randomized block design with three replicates. 
During the growing season, the plants were managed under commonly used agronomic and irrigation practices. The experimental design is provided in Table 1 . The fertilizer was supplied to the soil directly. The nutrient content of the fertilizer was $15 \% \mathrm{~N}, 15 \%$ $\mathrm{P}_{2} \mathrm{O}_{5}$, and $15 \% \mathrm{~K}_{2} \mathrm{O}$. SNP was supplied to the soil directly, via or by the slow-release way, or via foliar application. The slow-release SNP was provided by the Chinese National Engineering Research Center for Slow/Controlled Release Fertilizers. The amount of SNP added directly to the soil was $2.62 \mathrm{mg}$. The same quantity of SNP was added to a small paper bag and a capsule or developed into a slow-release particle. The three slow-release materials were used for root application. SNP solution was sprayed onto the leaves when the seedlings were 10 days old. Every pot was sprayed once per day with $10-\mathrm{mL}$ in the evening. The total quantity of foliar SNP application was consistent with that added into the soil.

\subsection{Plant growth and chlorophyll content analysis}

The plants from each treatment were carefully uprooted, and the stem height was recorded. The plants were washed with tap water to remove adhering foreign particles. The roots were removed, and the individual shoot FW was recorded. The shoots weredried at 80 ${ }^{\circ} \mathrm{C}$ for $48 \mathrm{~h}$, and their DW were recorded. A portable chlorophyll meter (SPAD-502, Konica Minolta Sensing, Inc., Japan) was used to measure changes in leaf greenness during processing (Neufeld et al., 2006).

\subsection{Plant biochemical analysis}

Leaf relative water content (LRWC) was measured by adopting the method of Yamasaki and Dillenburg (1999). Ten leaves were obtained for each treatment. To minimize the age effect, leaves were collected from the mid-section of the plant. To obtain their FW, the leaves were weighed immediately following removal from the stem. To determine turgid weight (TW), the leaves were kept in distilled water inside a Petri dish covered with its lid for $4 \mathrm{~h}$. Subsequently, the water was gently wiped from the leaf surface with tissue paper, and the leaves were weighed. To determine DW, the leaf samples were dried at $80^{\circ} \mathrm{C}$ for $24 \mathrm{~h}$. FW, TW and DW values were used to calculate LRWC using the following equation: LRWC $(\%)=(\mathrm{FW}-\mathrm{DW}) /(\mathrm{TW}-$ DW) $\times 100$.

To assess membrane permeability, electrolyte leakage was determined using the method of Tariq et al. (2011). Leaf samples were washed three times with distilled water to remove surface contaminants. Young leaf discs were placed in a vial containing $10 \mathrm{~mL}$ of distilled water which was closed and incubated on a rotatory shaker for $24 \mathrm{~h}$. Subsequently, the electrical conductivity $\left(\mathrm{EC}_{1}\right)$ of the solution was determined. The samples were then autoclaved at $120{ }^{\circ} \mathrm{C}$ for 20 min, and the final electrical conductivity $\left(\mathrm{EC}_{2}\right)$ was noted after cooling the solution at room temperature. Electrolyte leakage was calculated as follows: Electrolyte leakage $(\%)=\left(\mathrm{EC}_{1} / \mathrm{EC}_{2}\right) \times 100$.

Table 1. The experimental design

\begin{tabular}{lcl}
\hline No. & Code & Treatment \\
\hline CK & CK & $0.27 \mathrm{~g} \mathrm{~kg}^{-1}$ fertilizer alone \\
T1 & NaCl & $0.27 \mathrm{~g} \mathrm{~kg}^{-1}$ fertilizer and $585 \mathrm{mg} \mathrm{kg}^{-1} \mathrm{NaCl}$ \\
T2 & Slow-release bag & $0.27 \mathrm{~g} \mathrm{~kg}^{-1}$ fertilizer, $585 \mathrm{mg} \mathrm{kg}$ NaCl, and SNP added to a paper bag \\
T3 & Slow-release capsule & $0.27 \mathrm{~g} \mathrm{~kg}^{-1}$ fertilizer, $585 \mathrm{mg} \mathrm{kg}$ NaCl, and SNP added to a capsule \\
T4 & Slow-release particle & $0.27 \mathrm{~g} \mathrm{~kg}^{-1}$ fertilizer, $585 \mathrm{mg} \mathrm{kg}$ NaCl, and slow release particles containing SNP \\
T5 & Foliar application & $0.27 \mathrm{~g} \mathrm{~kg}^{-1}$ fertilizer, $585 \mathrm{mg} \mathrm{kg}^{-1} \mathrm{NaCl}$, and foliar application of $0.09 \mathrm{mM} \mathrm{SNP}$ \\
T6 & SNP applied into soil directly & $0.27 \mathrm{~g} \mathrm{~kg}^{-1}$ fertilizer, $585 \mathrm{mg} \mathrm{kg}^{-1} \mathrm{NaCl}$, and direct application of SNP into the soil \\
\hline
\end{tabular}

Note: All the treatments in other Tables and Figures (CK and T1 to T6) are in accordance with the descriptions in Table 1 
To measure the $\mathrm{O}_{2}$ generation rate, $0.3 \mathrm{~g}$ of fresh leaves were ground in liquid $\mathrm{N}_{2}$ and extracted in 3 $\mathrm{mL}$ of ice-cold $50 \mathrm{mM}$ phosphate buffer saline (PBS) $\left(\mathrm{pH}\right.$ 7.0). The $\mathrm{O}_{2}-$ generation rate was determined by monitoring the $\mathrm{A}_{530}$ of the hydroxylamine reaction following a modified method described by $\mathrm{He}$ et al. (2005). A 1-mL aliquot of the supernatant of a fresh leaf extract was added to $0.9 \mathrm{~mL}$ of $65 \mathrm{mM}$ PBS (pH 7.8) and $0.1 \mathrm{~mL}$ of $10 \mathrm{mM}$ hydroxyl ammonium chloride. The reaction was incubated at $25^{\circ} \mathrm{C}$ for 35 min. Solution $(0.5 \mathrm{~mL})$ from above reaction mixture described above was then added to $0.5 \mathrm{~mL}$ of $17 \mathrm{mM}$ sulfonic acid and $0.5 \mathrm{~mL}$ of $7.8 \mathrm{mM}$ a-naphthylamine solution. After a 20 -min reaction, $2 \mathrm{~mL}$ of ether was added and mixed well. The solution was centrifuged at $1500 \times \mathrm{g}$ at $4{ }^{\circ} \mathrm{C}$ for $5 \mathrm{~min}$.

The absorbance of the pink supernatant was measured at $530 \mathrm{~nm}$ with a spectrophotometer. The absorbance values were calibrated to a standard curve generated with known concentrations of $\mathrm{HNO}_{2}$.

For the measurement of hydrogen peroxide $\left(\mathrm{H}_{2} \mathrm{O}_{2}\right)$ concentration, $1 \mathrm{~g}$ of a fresh sample was homogenized in $2 \mathrm{~mL}$ of ice-cold acetone. Titanium reagent $(2 \%$ $\mathrm{TiCl}_{2}$ in conc. $\mathrm{HCl}$ ) was added to a known volume of the extract supernatant to give a Ti (IV) concentration of $2 \%$. The $\mathrm{Ti}^{-} \mathrm{H}_{2} \mathrm{O}_{2}$ complex, together with unreacted $\mathrm{Ti}$, was then precipitated by adding $0.2 \mathrm{~mL}$ of a 17 $\mathrm{M}$ ammonia solution for each $1 \mathrm{~mL}$ of extract. The precipitate was washed five times with ice-cold acetone by resuspension, drained, and dissolved in $1 \mathrm{M} \mathrm{H}_{2} \mathrm{SO}_{4}$ $(3 \mathrm{~mL})$. The absorbance of the solution was measured at $410 \mathrm{~nm}$ against blanks that had been prepared similarly but lacked plant tissue (Tariq et al., 2011).

Malondialdehyde (MDA) content is determined via the thiobarbituric acid reaction method (Heath and Packer, 1968). The supernatant from the antioxidant enzyme extraction was used for an MDA content assay. The MDA content was expressed as $\mu \mathrm{mol} \mathrm{g}^{-1} \mathrm{FW}$.

Proline was determined as described by Kojić et al. (2012). Briefly, plant material was homogenized in 3\% aqueous sulfosalicylic acid and the resulting homogenate was centrifuged for $10 \mathrm{~min}$ at 10000 $\mathrm{rpm}$. The supernatant was then used to estimate proline content. A reaction mixture consisting of 2 $\mathrm{mL}$ of supernatant, $2 \mathrm{~mL}$ of acid ninhydrin $(1.25 \mathrm{~g}$ of ninhydrin in $30 \mathrm{~mL}$ of glacial acetic acid and $60 \mathrm{~mL}$ of $6 \mathrm{M}$ phosphoric acid) and $2 \mathrm{~mL}$ of glacial acetic acid was boiled at $100{ }^{\circ} \mathrm{C}$ for $1 \mathrm{~h}$. The reactions were then terminated in an ice bath. The resulting reaction mixture was extracted with $4 \mathrm{~mL}$ of toluene, and the absorbance of the proline-ninhydrin chromophore was measured at $520 \mathrm{~nm}$. The proline concentration was determined from a standard curve and calculated on a fresh weight basis ( $\mu$ g proline $\mathrm{g}-1$ of FW material).

ASA was determined spectrophotometrically following the 2,4-dinitrophenylhydrazine colorimetry method described by Bao (2002). ASA was assayed in a similar manner except that $200 \mu \mathrm{L}$ of deionized $\mathrm{H}_{2} \mathrm{O}$ was substituted for DTT and N-ethylmaleimide. Color was developed in both series of reaction mixtures with the addition of $400 \mu \mathrm{L}$ of $10 \%(\mathrm{w} / \mathrm{v})$ trichloroacetic acid (TCA), $400 \mu \mathrm{L}$ of $44 \%(\mathrm{v} / \mathrm{v})$ o-phosphoric acid, $400 \mu \mathrm{L} \alpha-\alpha$ 'dipyridyl in $70 \%$ (v/v) ethanol and $200 \mu \mathrm{L}$ of $30 \mathrm{~g} \mathrm{l}^{-1} \mathrm{FeCl}_{3}$. The reaction mixtures were incubated at $40{ }^{\circ} \mathrm{C}$ for $1 \mathrm{~h}$ and quantified spectrophotometrically at $525 \mathrm{~nm}$.

For the determination of $\mathrm{Na}, \mathrm{K}, \mathrm{Ca}, \mathrm{Mg}$, and $\mathrm{Fe}$ concentrations, powdered dried sample mixtures were digested in an acid mixture $\left(\mathrm{HNO}_{3}-\mathrm{HClO}_{4}\right.$ [3:1]) and briefly centrifuged. $\mathrm{Na}, \mathrm{K}, \mathrm{Ca}, \mathrm{Mg}$, and $\mathrm{Fe}$ concentrations were determined using an atomic absorption spectrophotometer (SHIMADZU AA6300, Kyoto, Japan).

To extract antioxidant enzymes, leaves and roots were homogenized with $50 \mathrm{mM} \mathrm{Na} \mathrm{NPO}_{4}-\mathrm{NaH}_{2} \mathrm{PO}_{4}$ buffer $(\mathrm{pH} 7.8)$ containing $0.2 \mathrm{mM}$ EDTA and $2 \%$ insoluble polyvinylpyrrolidone (PVP) using a chilled mortar and pestle. The homogenate was centrifuged at $12000 \times \mathrm{g}$ for $20 \mathrm{~min}$, and the resulting supernatant was used for determination of enzyme activities. The entire extraction procedure was carried out at $4{ }^{\circ} \mathrm{C}$. 
All spectrophotometric analysis was conducted using a SHIMADZU UV-2450 spectrophotometer (Kyoto, Japan). SOD activity was assayed by measuring its ability to inhibit the photochemical reduction of nitroblue tetrazolium following the method of Tariq et al. (2011). CAT activity was measured as the decline in absorbance at $240 \mathrm{~nm}$ due to the decrease in $\mathrm{H}_{2} \mathrm{O}_{2}$ extinction according to the method of Tariq et al. (2011). POD activity was measured by the increase in absorbance at $470 \mathrm{~nm}$ due to guaiacol oxidation (Zhang et al., 2012).

\subsection{Statistical analysis}

Each pot was treated as one replicate, and all the treatments were repeated three times. Excel 2003 software was used to process data and constructed the tables, DPS software (DPS 7.05) was used for statistical analysis, and the least significant difference (LSD) was calculated to compare the differences between means in each treatment.

Table 2. Effects of salinity $(\mathrm{NaCl})$ and sodium nitroprusside (SNP) supplied via different application methods on the growth attributes and chlorophyll content of cotton seedlings grown in saline soil.

\begin{tabular}{cccccc}
\hline Treatment & $\begin{array}{c}\text { Plant height } \\
(\mathrm{cm})\end{array}$ & $\begin{array}{c}\text { Root length per plant } \\
(\mathrm{cm})\end{array}$ & $\begin{array}{c}\text { Dry weight per plant } \\
(\mathrm{g})\end{array}$ & $\begin{array}{c}\text { Fresh weight per plant } \\
(\mathrm{g})\end{array}$ & SPAD reading \\
\hline CK & $17.67 \pm 1.53 \mathrm{ab}$ & $9.50 \pm 0.051 \mathrm{c}$ & $0.44 \pm 0.11 \mathrm{ab}$ & $3.94 \pm 0.69 \mathrm{ab}$ & $45.13 \pm 2.20 \mathrm{ab}$ \\
T1 & $12.68 \pm 2.08 \mathrm{c}$ & $5.67 \pm 0.58 \mathrm{~d}$ & $0.25 \pm 0.08 \mathrm{c}$ & $1.83 \pm 0.42 \mathrm{~d}$ & $37.53 \pm 6.22 \mathrm{~d}$ \\
T2 & $17.33 \pm 1.52 \mathrm{ab}$ & $5.90 \pm 0.85 \mathrm{c}$ & $0.47 \pm 0.04 \mathrm{ab}$ & $3.40 \pm 0.42 \mathrm{ab}$ & $42.37 \pm 2.27 \mathrm{bcd}$ \\
T3 & $16.96 \pm 1.02 \mathrm{ab}$ & $13.17 \pm 4.19 \mathrm{~b}$ & $0.35 \pm 0.05 \mathrm{bc}$ & $2.53 \pm 0.55 \mathrm{~cd}$ & $39.03 \pm 1.60 \mathrm{~cd}$ \\
T4 & $17.83 \pm 1.26 \mathrm{ab}$ & $18.83 \pm 2.57 \mathrm{a}$ & $0.46 \pm 0.14 \mathrm{ab}$ & $3.21 \pm 0.24 \mathrm{bc}$ & $45.60 \pm 2.10 \mathrm{ab}$ \\
T5 & $19.33 \pm 2.89 \mathrm{a}$ & $17.27 \pm 0.75 \mathrm{a}$ & $0.56 \pm 0.08 \mathrm{a}$ & $4.08 \pm 0.36 \mathrm{a}$ & $49.47 \pm 3.30 \mathrm{a}$ \\
T6 & $15.67 \pm 3.21 \mathrm{bc}$ & $6.90 \pm 0.36 \mathrm{~cd}$ & $0.34 \pm 0.06 \mathrm{bc}$ & $2.23 \pm 0.48 \mathrm{~d}$ & $44.47 \pm 3.35 \mathrm{abc}$ \\
\hline
\end{tabular}

Note: Values represent the mean \pm S.D. $(\mathrm{n}=3)$. Different lowercase letters indicate significant differences at $p<0.05$.

\section{Results}

\subsection{Growth parameters and chlorophyll content}

$\mathrm{NaCl}$ exposure significantly decreased the plant height and root length of cotton seedlings (Table 2); however, this inhibition was alleviated by SNP addition, especially in the T4 and T5 treatments. Compared with $\mathrm{NaCl}$ treatment, the height and root length of plants subjected to T4 treatment were increased by $40.62 \%$ and $232.10 \%$, respectively; T5 treatment increased these values by $52.44 \%$ and $204.59 \%$, respectively. $\mathrm{NaCl}$ treatment significantly decreased the FW and DW of cotton plants; however, this was significantly ameliorated by SNP addition $(p<0.05)$. Chlorophyll content was also reduced in salt-stressed plants, with the most severe effects noted in the $\mathrm{T} 4$ and $\mathrm{T} 5$ treatments (Table 2).

\subsection{Leaf relative water content ( $L R W C$ )}

The effects of salt stress and SNP on LRWC are shown in Table 3. Treatment with excess $\mathrm{NaCl}$ significantly decreased the LRWC in the leaves, and the addition of SNP alleviated the decreases, especially when the slow-release particle and foliar application methods were employed.

\subsection{Electrolyte leakage}

As shown in Table 3, plants supplemented with $\mathrm{NaCl}$ exhibited a significant increase in electrolyte leakage compared with the plants grown in non-saline soil.

NO decreased electrolyte leakage in the plants grown with $\mathrm{NaCl}$. Slow-release particle and foliar application methods were found to be more effective in the 
amelioration of $\mathrm{NaCl}$ stress and caused a significant decrease in electrolyte leakage.

\subsection{Lipid peroxidation}

Oxidative damage to tissue lipids was assessed by determining total MDA content. $\mathrm{NaCl}$-generated stress induced MDA production (Table 3). The application of SNP to NaCl-treated plants decreased the MDA content. The maximal alleviation of salt stress was recorded in the plants treated with slow-release particles, as reflected by $26.92 \%$ and $41.67 \%$ decreased in leaf and root MDA compared with saltstressed plants.

Table 3. Effects of salinity $(\mathrm{NaCl})$ and sodium nitroprusside (SNP) supplied via different application methods on leaf relative water content, electrolyte leakage, lipid peroxidation and endogenous ROS production of cotton seedlings grown in saline soil.

\begin{tabular}{|c|c|c|c|c|c|c|c|}
\hline \multirow{2}{*}{ Treatments } & \multirow{2}{*}{ LRWC (\%) } & \multirow{2}{*}{$\begin{array}{l}\text { Electrolyte } \\
\text { leakage (\%) }\end{array}$} & \multicolumn{2}{|c|}{$\begin{array}{l}\text { Lipid peroxidation } \\
\left(\mu \mathrm{mol} \cdot \mathrm{g}^{-1} \mathrm{FW}\right)\end{array}$} & \multicolumn{2}{|c|}{$\begin{array}{l}\mathrm{O}_{2} \text { generation rate } \\
\left(\mu \mathrm{mol} \cdot \mathrm{g}^{-1} \cdot \mathrm{h}^{-1} \mathrm{FW}\right)\end{array}$} & \multirow{2}{*}{$\begin{array}{c}\mathrm{H}_{2} \mathrm{O}_{2} \\
\left(\mu \mathrm{mol} \cdot \mathrm{g}^{-1} \mathrm{FW}\right)\end{array}$} \\
\hline & & & Leaves & Root & Leaves & Root & \\
\hline CK & $0.96 \pm 0.03 a$ & $0.30 \pm 0.04 \mathrm{c}$ & $0.017 \pm 0.002 \mathrm{e}$ & $0.008 \pm 0.004 c$ & $1.33 \pm 0.26 \mathrm{c}$ & $4.96 \pm 0.95 \mathrm{e}$ & $0.91 \pm 0.13 \mathrm{~d}$ \\
\hline $\mathrm{T} 1$ & $0.82 \pm 0.02 c$ & $0.69 \pm 0.03 \mathrm{a}$ & $0.026 \pm 0.004 a$ & $0.012 \pm 0.008 \mathrm{a}$ & $2.33 \pm 0.59 \mathrm{a}$ & $19.80 \pm 0.42 \mathrm{a}$ & $3.01 \pm 0.23 a$ \\
\hline T2 & $0.92 \pm 0.02 \mathrm{ab}$ & $0.64 \pm 0.12 \mathrm{a}$ & $0.022 \pm 0.001 \mathrm{c}$ & $0.011 \pm 0.015 b$ & $2.03 \pm 0.28 \mathrm{ab}$ & $11.02 \pm 0.65 c$ & $2.31 \pm 0.06 \mathrm{~b}$ \\
\hline T3 & $0.91 \pm 0.04 \mathrm{~b}$ & $0.66 \pm 0.05 a$ & $0.022 \pm 0.007 \mathrm{c}$ & $0.005 \pm 0.002 \mathrm{e}$ & $1.86 \pm 0.15 \mathrm{abc}$ & $13.96 \pm 0.84 b$ & $2.22 \pm 0.31 \mathrm{~b}$ \\
\hline $\mathrm{T} 4$ & $0.93 \pm 0.01 \mathrm{ab}$ & $0.29 \pm 0.08 c$ & $0.019 \pm 0.003 \mathrm{~d}$ & $0.007 \pm 0.001 \mathrm{~d}$ & $1.78 \pm 0.03 \mathrm{bc}$ & $9.51 \pm 0.71 d$ & $2.02 \pm 0.02 b c$ \\
\hline T5 & $0.95 \pm 0.07 \mathrm{ab}$ & $0.53 \pm 0.08 \mathrm{~b}$ & $0.019 \pm 0.011 \mathrm{~d}$ & $0.010 \pm 0.001 b$ & $1.77 \pm 0.39 b c$ & $12.23 \pm 1.00 \mathrm{c}$ & $1.78 \pm 0.39 \mathrm{c}$ \\
\hline $\mathrm{T} 6$ & $0.84 \pm 0.12 \mathrm{c}$ & $0.69 \pm 0.16 \mathrm{a}$ & $0.023 \pm 0.006 \mathrm{~b}$ & $0.011 \pm 0.010 \mathrm{a}$ & $2.19 \pm 0.03 \mathrm{ab}$ & $13.67 \pm 0.24 b$ & $2.81 \pm 0.09 \mathrm{a}$ \\
\hline
\end{tabular}

Note: Values represent the mean \pm S.D. $(n=3)$. Different lowercase letters indicate significant differences at $p<0.05$.

\subsection{Endogenous ROS production}

Overaccumulation of ROS in plant cells is the main effect of salt stress. As shown in Table 3, $\mathrm{NaCl}$ stress induced a dramatic increase in $\mathrm{O}_{2}{ }^{-}$and $\mathrm{H}_{2} \mathrm{O}_{2}$ production in the roots and leaves of cotton seedlings compared with the CK. SNP applied directly into soil had no effect on $\mathrm{O}_{2}-$ content in the leaves but markedly decreased $\mathrm{O}_{2}-$ accumulation in the root. SNP added to a capsule, a paper bag and slow-release particles or sprayed onto leaves markedly diminished $\mathrm{NaCl}$-induced $\mathrm{O}_{2}$. accumulation in the roots and leaves; this effect was especially obvious with slow-release particles.

The lowest values for $\mathrm{H}_{2} \mathrm{O}_{2}$ content were recorded in the non-stressed plants, and plants grown with $\mathrm{NaCl}$ accumulated the maximum $\mathrm{H}_{2} \mathrm{O}_{2}$ content. The application of $\mathrm{NO}$ to salt-stressed plants reduced the
$\mathrm{H}_{2} \mathrm{O}_{2}$ content, and $\mathrm{T} 5$ treatment effectively alleviated the adverse effect of $\mathrm{NaCl}$ on this parameter. Used of slow-release particles arrested the effect of salt stress up to a considerable limit and caused a $32.89 \%$ decrease in $\mathrm{H}_{2} \mathrm{O}_{2}$ content compared with the plants grown with $\mathrm{NaCl}$ only.

\subsection{ASA and proline content}

Proline levels were higher in NaCl-treated plants compared with the control (Figure 1A). The application of NO to stressed plants could significantly alter the proline level when compared with control plants. The lowest level of proline was observed in the saltstressed plants, which were subjected to NO spraying. ASA content significantly increased in $\mathrm{NaCl}$-stressed plants compared to the control (Figure 1B). The ASA level was higher in stressed plants supplied with NO 
compared with salt-stressed plants. In addition, slow-release particle and foliar application methods triggered the plants to accumulate additional ASA content.

\section{7. $\mathrm{Na}, \mathrm{K}, \mathrm{Ca}, \mathrm{Mg}$, and Fe contents}

$\mathrm{NaCl}$ treatment dramatically increased the $\mathrm{Na}$ concentration in the leaves, stems, and roots. However, addition of $\mathrm{NO}$ greatly decreased the $\mathrm{Na}$ concentration in the leaves and stems and increased $\mathrm{Na}$ concentration in the roots under excess $\mathrm{NaCl}$.

Treatment with excess $\mathrm{NaCl}$ did not significantly influence the $\mathrm{Mg}$ concentration in the leaves; however, excess $\mathrm{NaCl}$ decreased the $\mathrm{Mg}$ concentration in the stems and roots. Excess $\mathrm{NaCl}$ significantly decreased the $\mathrm{Ca}$ concentration in the leaves, stems, and roots; however, the addition of $\mathrm{NO}$, especially the $\mathrm{T} 4$ and $\mathrm{T} 5$ treatments, significantly increased the $\mathrm{Ca}$ and $\mathrm{Mg}$ concentration under excess $\mathrm{NaCl}$. As shown in Table 4, $\mathrm{NaCl}$ treatment significantly decreased the $\mathrm{Fe}$ concentration in the leaves, stems, and roots, and the addition of NO alleviated the decreases in the leaves and stem. The $\mathrm{T} 5$ treatment increased the $\mathrm{Fe}$ concentration in the leaves, and the $\mathrm{T} 4$ treatment significantly increased the $\mathrm{Fe}$ concentration in the stem and root.

\subsection{Antioxidant enzymes}

The activities of several representative antioxidant enzymes, including SOD, POD, and CAT, were determined in cotton seedlings to assess how SNP application affects the regulation of these antioxidant enzymes upon $\mathrm{NaCl}$ stress. As shown in Figure 2, $\mathrm{NaCl}$ increased SOD, POD, and CAT activity in the leaves, and a combined treatment including excess $\mathrm{Na}$ and SNP stimulated enzyme activity to a much greater extent. Unlike in leaves, $\mathrm{NaCl}$ decreased the SOD and POD activity in the root; however, use of slow-release capsule, slow-release bag and slow-release particle increased the activity compared with $\mathrm{NaCl}$ treatment. Foliar SNP application was optimal for increasing CAT activities in leaves, and slow-release particles were optimal for increasing SOD activities in roots.

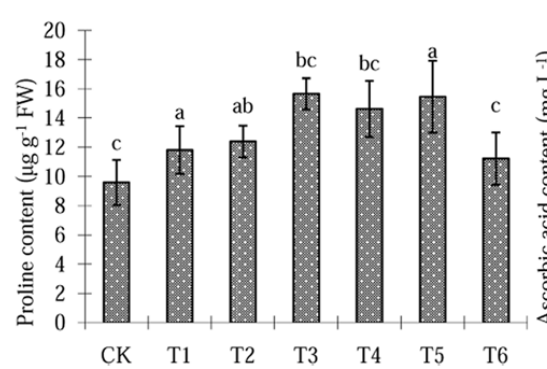

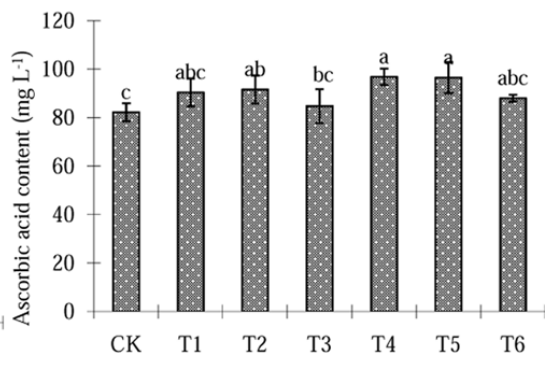

Figure 1. Effects of salinity $(\mathrm{NaCl})$ and sodium nitroprusside $(\mathrm{SNP})$ supplied via different application methods on the proline content (A) and ascorbic acid content (B) of cotton seedlings grown in saline soil. Note: Values represent the mean \pm S.D. $(n=3)$. Different lowercase letters indicate significant differences at $p<0.05$. 
Table 4. Effects of salinity $(\mathrm{NaCl})$ and sodium nitroprusside (SNP) supplied via different application methods on the $\mathrm{Na}(\%), \mathrm{K}(\%), \mathrm{Ca}\left(\mathrm{g} \mathrm{kg}^{-1)}, \mathrm{Mg}\left(\mathrm{g} \mathrm{kg}^{-1}\right)\right.$ and $\mathrm{Fe}\left(\mathrm{mg} \mathrm{kg}^{-1}\right)$ contents of cotton seedlings grown in saline soil.

\begin{tabular}{|c|c|c|c|c|c|c|c|c|}
\hline \multirow{2}{*}{\multicolumn{2}{|c|}{$\begin{array}{l}\text { Element/Type of } \\
\text { plant tissue }\end{array}$}} & \multicolumn{7}{|c|}{ Treatments } \\
\hline & & $\mathrm{CK}$ & $\mathrm{T} 1$ & $\mathrm{~T} 2$ & T3 & $\mathrm{T} 4$ & T5 & T6 \\
\hline \multirow{4}{*}{$\mathrm{Na}$} & Leaves & $0.016 \pm 0.01 \mathrm{c}$ & $0.168 \pm 0.05 a$ & $0.131 \pm 0.06 \mathrm{~b}$ & $0.179 \pm 0.02 \mathrm{a}$ & $0.135 \pm 0.07 b$ & $0.141 \pm 0.01 \mathrm{~b}$ & $0.142 \pm 0.03 \mathrm{~b}$ \\
\hline & Stem & $0.016 \pm 0.02 \mathrm{c}$ & $0.167 \pm 0.05 a$ & $0.162 \pm 0.01 \mathrm{a}$ & $0.150 \pm 0.08 \mathrm{ab}$ & $0.136 \pm 0.13 b$ & $0.151 \pm 0.22 \mathrm{a}$ & $0.160 \pm 0.06 \mathrm{a}$ \\
\hline & Root & $0.053 \pm 0.02 \mathrm{c}$ & $0.328 \pm 0.03 a$ & $0.349 \pm 0.06 \mathrm{a}$ & $0.336 \pm 0.03 \mathrm{~b}$ & $0.273 \pm 0.01 \mathrm{~b}$ & $0.331 \pm 0.04 a$ & $0.349 \pm 0.02 \mathrm{a}$ \\
\hline & Leaves & $0.37 \pm 0.06 \mathrm{~b}$ & $0.19 \pm 0.07 \mathrm{c}$ & $0.20 \pm 0.07 \mathrm{c}$ & $0.50 \pm 0.03 \mathrm{a}$ & $0.50 \pm 0.04 a$ & $0.51 \pm 0.03 \mathrm{a}$ & $0.30 \pm 0.11 \mathrm{bc}$ \\
\hline \multirow[t]{3}{*}{$\mathrm{K}$} & Stem & $0.36 \pm 0.09 \mathrm{~cd}$ & $0.22 \pm 0.02 \mathrm{e}$ & $0.47 \pm 0.08 \mathrm{bc}$ & $0.65 \pm 0.06 \mathrm{a}$ & $0.27 \pm 0.03 \mathrm{de}$ & $0.31 \pm 0.10 \mathrm{de}$ & $0.50 \pm 0.10 \mathrm{~b}$ \\
\hline & Root & $1.05 \pm 0.07 \mathrm{~b}$ & $0.83 \pm 0.02 \mathrm{c}$ & $1.28 \pm 0.07 \mathrm{a}$ & $0.85 \pm 0.06 c$ & $0.98 \pm 0.05 b$ & $0.66 \pm 0.09 \mathrm{~d}$ & $0.57 \pm 0.09 \mathrm{~d}$ \\
\hline & Leaves & $1.25 \pm 0.20 \mathrm{ab}$ & $1.31 \pm 0.12 \mathrm{a}$ & $0.64 \pm 0.25 d$ & $1.27 \pm 0.13 \mathrm{ab}$ & $0.97 \pm 0.08 \mathrm{bc}$ & $0.67 \pm 0.17 d$ & $0.78 \pm 0.17 \mathrm{~cd}$ \\
\hline \multirow[t]{3}{*}{$\mathrm{Mg}$} & Stem & $1.61 \pm 0.25 \mathrm{a}$ & $0.82 \pm 0.08 \mathrm{bc}$ & $0.77 \pm 0.04 \mathrm{c}$ & $0.74 \pm 0.04 \mathrm{c}$ & $0.96 \pm 0.10 \mathrm{~b}$ & $0.90 \pm 0.05 b c$ & $0.72 \pm 0.02 c$ \\
\hline & Root & $1.50 \pm 0.02 \mathrm{a}$ & $0.78 \pm 0.12 c$ & $1.27 \pm 0.23 \mathrm{ab}$ & $1.08 \pm 0.05 b$ & $1.28 \pm 0.06 \mathrm{ab}$ & $1.43 \pm 0.18 \mathrm{a}$ & $1.50 \pm 0.28 \mathrm{a}$ \\
\hline & Leaves & $8.14 \pm 0.41 \mathrm{a}$ & $5.11 \pm 0.93 \mathrm{~cd}$ & $5.12 \pm 0.20 \mathrm{~cd}$ & $4.67 \pm 0.39 d$ & $6.49 \pm 0.53 b$ & $6.41 \pm 0.12 b$ & $5.69 \pm 0.20 \mathrm{bc}$ \\
\hline \multirow[t]{3}{*}{$\mathrm{Ca}$} & Stem & $9.76 \pm 0.92 \mathrm{a}$ & $5.97 \pm 0.88 d$ & $6.29 \pm 1.09 \mathrm{~cd}$ & $7.54 \pm 0.13 \mathrm{bcd}$ & $8.84 \pm 0.73 \mathrm{ab}$ & $7.68 \pm 0.30 \mathrm{bc}$ & $6.93 \pm 1.53 \mathrm{~cd}$ \\
\hline & Root & $3.34 \pm 0.15 \mathrm{a}$ & $1.93 \pm 0.07 \mathrm{c}$ & $2.32 \pm 0.41 \mathrm{c}$ & $2.42 \pm 0.11 b c$ & $3.11 \pm 0.09 \mathrm{ab}$ & $3.14 \pm 0.23 \mathrm{ab}$ & $3.15 \pm 1.05 \mathrm{ab}$ \\
\hline & Leaves & $1.30 \pm 0.22 \mathrm{a}$ & $0.44 \pm 0.12 c$ & $0.68 \pm 0.19 b c$ & $0.94 \pm 0.076 b c$ & $0.79 \pm 069 \mathrm{abc}$ & $1.03 \pm 0.18 \mathrm{ab}$ & $0.80 \pm 0.31 \mathrm{abc}$ \\
\hline \multirow[t]{2}{*}{$\mathrm{Fe}$} & Stem & $2.94 \pm 0.11 \mathrm{~b}$ & $1.37 \pm 0.11 \mathrm{c}$ & $1.16 \pm 0.20 \mathrm{c}$ & $1.27 \pm 0.18 c$ & $3.55 \pm 1.07 \mathrm{a}$ & $2.64 \pm 0.44 \mathrm{~b}$ & $1.34 \pm 0.49 c$ \\
\hline & Root & $1.98 \pm 0.04 \mathrm{a}$ & $1.05 \pm 0.18 c$ & $1.62 \pm 0.38 \mathrm{~b}$ & $1.61 \pm 0.06 \mathrm{~b}$ & $1.70 \pm 0.15 \mathrm{ab}$ & $1.69 \pm 0.16 \mathrm{ab}$ & $1.55 \pm 0.11 \mathrm{~b}$ \\
\hline
\end{tabular}

Note: Values represent the mean \pm S.D. $(\mathrm{n}=3)$. Different lowercase letters indicate significant differences at $p<0.05$.
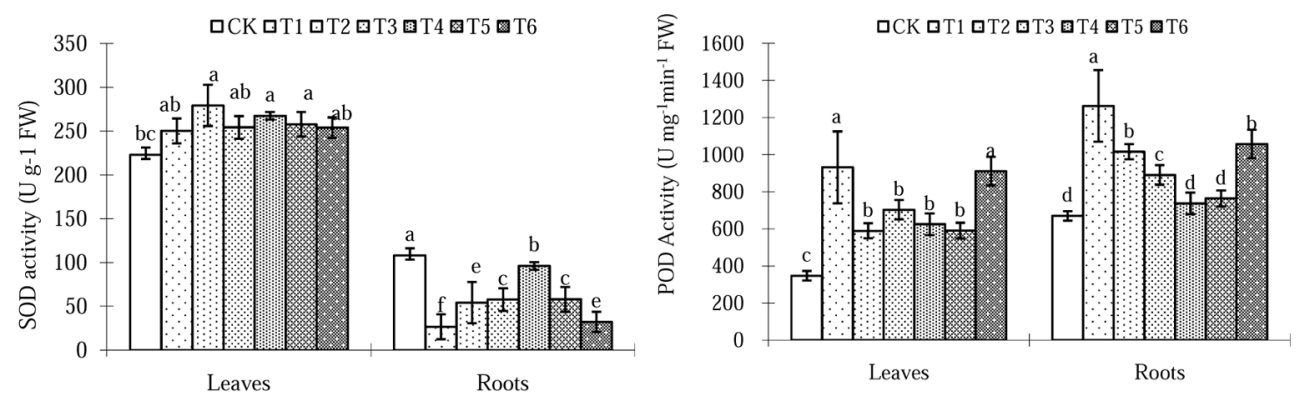

C

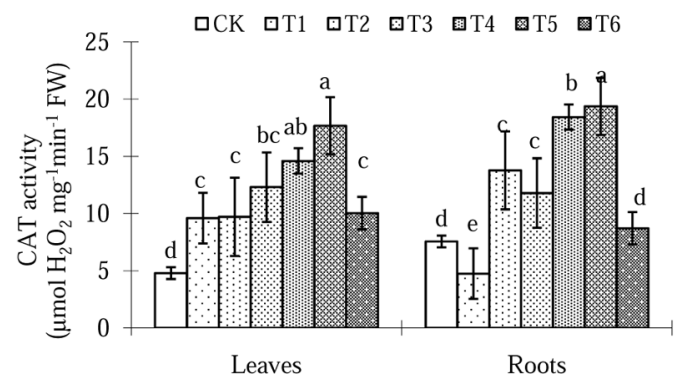

Figure 2. Effects of salinity $(\mathrm{NaCl})$ and sodium nitroprusside (SNP) supplied via different application methods on the activities of SOD (A), POD (B), and CAT (C) in the leaves and roots of cotton plants grown in saline soil. Values represent the mean \pm S.D. $(\mathrm{n}=3)$. Different lowercase letters indicate significant differences at $p<0.05$. 


\section{Discussion}

In the present work, we provided evidence that different SNP application methods have different effects in salt tolerance. The results from the current experiments clearly indicated that the growth and quality of cotton seedlings grown in $\mathrm{NaCl}-$ contaminated soil were inhibited significantly (Table 2). The suppression of growth and quality might be due to enhanced production and accumulation of ROS, which damaged photosynthetic activity by decreasing chloroplastic pigments levels (Table 2). Similar results were reported in NaCl-treated linseed and cotton (Khan et al., 2010; Liu et al., 2013). The decline in chlorophyll content in cotton leaves is believed to be due to impairment in the supply of $\mathrm{Mg}^{2+}$ required for the synthesis of chlorophylls (Table 4). NaCl-induced chlorophyll synthesis inhibition was significantly reversed when cotton seedlings were treated with exogenous SNP. However, the application of SNP by various methods alleviated the inhibitory effects. Slow-release or foliar application of SNP improved the vegetative growth of plants, thereby increasing the fresh weight under saline conditions. The SNPinduced increase in the dry matter of cotton seedlings could be due to its membrane-protective role (Liu et al., 2013) and antioxidant activity (Gunes et al., 2007). Controlled release fertilizers are used to reduce fertilizer application frequency and reduce fertilizer waste when compared with other fertilizer systems (Ruter et al., 1992). Slow-release NO may reduce $\mathrm{NO}$ application frequency and NO waste to regulate ionic equilibrium and membrane function, thereby promoting growth.

External $\mathrm{NaCl}$ lowered the LRWC of cotton seedlings (Table 3). Similar results were reported in linseed and Brassica juncea seedlings (Khan et al., 2010d; Zeng et al., 2011). However, $\mathrm{NaCl}$ stress in association with SNP significantly enhanced LRWC. Parida and Das (2005) reported that the relative water content, water potential, and osmotic potential of plants become more negative with an increase in salinity. Treatment with SNP reduced membrane injury by dehydration and improved the water status of plants, which may be the reason for improved seedling growth under SNP treatments. Use of slow-release particles may improve water availability and uptake and weaken the ability of $\mathrm{Na}^{+}$to compete for membrane binding sites, resulting in enhanced uptake of other ions under saline conditions, as exhibited by increases in the LRWC level and leaf nutrient content.

Electrolyte leakage indicates cell membrane injury when plants subjected to salinity stress. NO application completely abolished the effects of salinity in plants grown with $\mathrm{NaCl}$ (Table 3). Similar findings were noted by Zeng et al. (2011) in Brassica juncea and by El-Tayeb et al. (2005) in barley. Both studies suggested that SNP facilitated the maintenance of membrane functions through induction of antioxidant mechanisms and elevated ion uptake, thereby protecting the plants against oxidative damage. It is well known that the degree of lipid peroxidation is closely related to the accumulation of ROS, and the lipid peroxidation process is one important factor that exerts an effect on ATPase under changing environmental conditions. Therefore, the ability of exogenous NO to decrease lipid peroxidation should be considered as one factor that maintains higher ATPase activity (Shi et al., 2007). In the present study, slow-release NO slows down the NO release rate and continuously delivered NO to cotton, thus sustained regulating the activity of ATPase to decrease lipid peroxidation.

Proline and ASA contents were increased in plants grown with $\mathrm{NaCl}$ alone and were further increased by SNP application (Figure 1). The accumulation of osmotic regulation substances facilitates the osmotic adjustment of plants. ASA plays an important role in the protection of plants against membrane lipid peroxidation. Proline is the major source of energy and nitrogen during immediate post-stress metabolism, and accumulated proline apparently supplies energy for growth and survival, thereby inducing salinity tolerance (Zeng et al., 2011). The increased accumulation of proline and ASA in SNP-treated plants counteracted the negative effects of salinity and 
might have aided the osmotic adjustment of plants. Thus, slow-release NO application improved plant salt tolerance, which was observed by an increase in contents of proline and ASA.

Exogenous SNP exerts various effects on the uptake of $\mathrm{K}, \mathrm{Ca}, \mathrm{Mg}$, and $\mathrm{Fe}$. A decrease in seedling micronutrient content $(\mathrm{K}, \mathrm{Ca}, \mathrm{Mg}$, and $\mathrm{Fe})$ and a significant increase in $\mathrm{Na}$ content were recorded in the plants grown with $\mathrm{NaCl}$ alone (Table 4). Under $\mathrm{NaCl}$ stress, higher concentrations of $\mathrm{K}, \mathrm{Ca}, \mathrm{Mg}$, and $\mathrm{Fe}$ were recorded when the plants were provided with slow-release $\mathrm{NO}$ compared with $\mathrm{NaCl}$ alone. Similar results were reported by Khan et al. (2010). Increased $\mathrm{K}$ and $\mathrm{Ca}$ contents due to the application of slow-release NO may be explained based on (1) the ability of $\mathrm{K}$ and $\mathrm{Ca}$ to replace $\mathrm{Na}$ as a result of mutual competition between the two ions for a transport site on a carrier protein or (2) a decrease in the magnitude of the $\mathrm{pH}$ gradient across the plasma membrane, resulting in reduced net influx of $\mathrm{Na}$ and inhibition of membrane-associated carrier proteins, thereby maintaining the balance of $\mathrm{K}$ and $\mathrm{Ca}$ (Khan et al., 2010). It is expected that cotton seedlings transported micronutrient contents to shoots, and maintained low $\mathrm{Na}^{+}$concentrations; these traits may help the plant adapt to saline environments. Also, the increased in leaf $\mathrm{Fe}$ content due to the foliar application of $\mathrm{NO}$ to salinity-affected plants may be explained based on $\mathrm{Fe}$ transfer to leaves, which may have occurred as a result of increased chlorophyll content due to an increase in the number of chloroplasts per cell.

ROS such as $\mathrm{O}_{2}-$ and $\mathrm{H}_{2} \mathrm{O}_{2}$ are often produced in large quantities by plants during various stress responses. The MDA content was measured as an index of lipid peroxidation. We investigated the involvement of these molecules in our experiments. The results showed that $\mathrm{NaCl}$-induced overaccumulation of $\mathrm{O}_{2}^{-}, \mathrm{H}_{2} \mathrm{O}_{2}$, and MDA in the roots and leaves of cotton was eliminated by the addition of SNP (Table 3 ). NO inhibits oxidation damage by regulating general mechanisms for cellular redox homeostasis, and promoting the transformation of $\mathrm{O}_{2}-$ to $\mathrm{H}_{2} \mathrm{O}$ and $\mathrm{O}_{2}$, and enhancing the activity of $\mathrm{H}_{2} \mathrm{O}_{2}$-scavenging enzymes (Shi et al., 2007; Fan et al., 2013). Slow-release bags, slow-release capsules and slow-release particles were all able to inhibit oxidative damage. Foliar SNP application also decreased the damage from reactive oxygen and inhibited MDA accumulation. ROS generated hydroxyl radicals and other destructive species such as lipid peroxides (Vaidyanathan et al., 2003), which leads to the destruction of the cell membrane as reflected by increased MDA levels under $\mathrm{NaCl}$ stress. Thus, scavenging ROS to maintain metabolic functions under salt stress is essential. Scavenging ROS depends on detoxification via the action of SOD and CAT. The results of the current study demonstrated that $\mathrm{NO}$ supplementation alleviates the $\mathrm{NaCl}$-induced inhibition of SOD, POD and CAT activities, especially when supplied via the three slow-release materials or by foliar application (Figure 2). Zeng et al. (2011) and Nounjan et al. (2012) also reported similar effects on the levels of antioxidants. In this regard, CAT and SOD appear to play an essential protective role in ROS scavenging (Tariq et al., 2011). SOD initiates detoxification of $\mathrm{O}_{2}^{-}$by producing $\mathrm{H}_{2} \mathrm{O}_{2}$, which is eliminated by its conversion to $\mathrm{H}_{2} \mathrm{O}$ in subsequent reactions. Furthermore, it is well known that the accumulated $\mathrm{Ca}$ might be responsible for the decreased MDA and $\mathrm{H}_{2} \mathrm{O}_{2}$ contents because $\mathrm{Ca}$ has a unique role in membrane stabilization (Hirschi et al., 2004). Thus, the NO-enhanced uptake of $\mathrm{Ca}$ into the cytoplasm in this experiment may decrease MDA and $\mathrm{H}_{2} \mathrm{O}_{2}$ contents and reduce oxidative stress. The induction of CAT and SOD activities by NO in salt-stressed cotton plants indicates that slow-release NO can play an important role in persistently modulating the cellular redox balance, thereby protecting plants against oxidative damage.

\section{Conclusion}

The present work revealed the effect of various methods of SNP application on the alleviation of $\mathrm{NaCl}$ toxicity in cotton seedlings. Foliar application 
can regulate ion absorption and maintaining normal metabolism and growth. However, foliar application is time-consuming because spraying must be performed every day. SNP release occurs differently in soil versus foliar application. The physiological mechanisms by which slow-release NO improves cotton salt tolerance involve the regulation of antioxidant system establishment and the reestablishment of the cyto-balance system, including the synthesis of osmotic protection components and restoration of ionic equilibrium. Significantly, it was found that slow-release particles released the highest amount of osmotic protection components. Thus, it might be concluded that SNP contained within the particle structure was slowly released into the soil and had long-lasting effect against oxidative stress during salt stress. Thus, SNP contained within slowrelease particles may be a new preparation that can be used to improve salt tolerance. However, further research is required to determine the changes in these physiological parameters at the molecular level.

\section{Acknowledgements}

This study was supported by the Shandong Provincial Natural Science Foundation, China. Project No. ZR2013CM003 and the Open Research Fund Program of Shandong Provincial Key Laboratory of Eco-Environmental Science for Yellow River Delta (Binzhou University), Project No. 2012KFJJ02.

\section{Reference}

Beligni, M.V., Lamattina, L. 2000. Nitric oxide stimulates seed germination and deetiolation, and inhibits hypocotyl elongation, three light-inducible responses in plants. Planta. 210, 215-221.

Bao, S.D. 2002. Soil and agricultural chemistry analysis, 3rd ed. China Agricultural, Beijing.
El-tayeb, M. 2005. Response of barley grains to the interactive effect of salinity and salicylic acid. Plant Growth Regul. 45, 215-224.

Fan, H.F., Du, C.X., Ding, L., Xu, Y.L. 2013. Effects of nitric oxide on the germination of cucumber seeds and antioxidant enzymes under salinity stress. Acta Physiol. Plant. 35, 2707-2719.

Gunes, A., Inal, A., Alpaslan, M., Eraslan, F., Bagci, E.G., Cicek, N. 2007. Salicylic acid induced changes on some physiological parameters symptomatic for oxidative stress and mineral nutrition in maize (Zea mays L.) grown under salinity. J. Plant Physiol. 164, 728-736.

Heath, RL, Packer L. 1968. Photoperoxidation in isolated chloroplasts. I: kinetics and stoichiometry of fatty acid peroxidation. Archives of Biochemistry and Biophysics. 125, 189-198.

Hirschi, K.D. 2004. The calcium conundrum. Both versatile nutrient and specific signal. Plant Physiol. 136, 2438-2442

He, Y., Liu, Y., Cao, W., Hua, M., Xu, B., Huang, B. 2005. Effects of salicylic acid on heat tolerance associated with antioxidant metabolism in Kentucky bluegrass. Crop Science. 45, 988-995.

Kojić, D., Pajević S., Jovanović-Galović, A., Purać, J., Pamer, E., Škondrić, S., Milovac, S., Popović, Ž., Grubor-Lajšić G. 2012. Efficacy of natural aluminosilicates in moderating drought effects on the morphological and physiological parameters of maize plants (Zea mays L.). J. Soil Sci. Plant Nutr. 12, 113-123.

Khan, M.N., Siddiqui, M.H., Mohammad, F., Naeem, M., Khan, M.M.A. 2010. Calcium chloride and gibberellic acid protect linseed (Linum usitatissimum L.) from $\mathrm{NaCl}$ stress by inducing antioxidative defence system and osmoprotectant accumulation. Acta Physiol Plant. 32, 121-132. 
Liu, S., Dong, Y.J., Xu, L.L., Kong, J., 2013. Effects of foliar applications of nitric oxide and salicylic acid on salt-induced changes in photosynthesis and antioxidative metabolism of cotton seedlings. Plant Growth Regul. DOI 10.1007/s10725-0139868-6.

Neufeld, H.S., Chappelka, A.H., Somers, G.L., Burkey, K.O., Davison A.W., Finkelstein P.L. 2006. Visible foliar injury caused by ozone alters the relationship between SPAD meter readings and chlorophyll concentrations in cutleaf coneflower. Photosynth. 87, 281-286.

Nounjan, N., Theerakulpisut, P. 2012. Effects of exogenous proline and trehalose on physiological response in rice seedlings during salt-stress and after recovery. Plant, Soil and Environment. 58, 309-315.

Parida, A.K., Das, A.B. 2005. Salt tolerance and salinity effects on plants: a review. Ecotoxicol. Environ. Safe. 60, 324-349.

Procházková, D., Haisel, D., Pavlíková, D., Schnablová, R., Száková, J., Vytášek, R., Wilhelmová, N. 2012. The effect of risk elements in soil to nitric oxide metabolism in tobacco plants. Plant, Soil and Environment. 58, 435-440.

Qadir, M., Noble, A.D., Schubert, S. Thomas, R.J., Arslan, A. 2006. Sodicity-induced land degradation and its sustainable management: problems and prospectives. Land Degrad Dev. 17, 661-676.

Ruter, J.M. 1992. Influence of source, rate, and method of applicating controlled release fertilizer on nutrient release and growth of "savannah" holly. Fertilizer Research. 32, 101-106.

Sheetal, C., Sunita, J., Veena, J. 2012. Salinity induced oxidative stress and antioxidant system in salt-tolerant and salt-sensitive cultivars of rice (Oryza sativa L.). Journal of plant biochemistry and biotechnology. DOI 10.1007/s13562-0120107-4.

Shi, H., Ishitani, M., Kim, C., Zhu, J. 2000. The Arabidopsis thaliana salt tolerance gene SOS1 encodes a putative Na1yH1 antiporter. PNAS. 97, 6896-6901.

Shi, Q., Ding, F., Wang, X., Wei, M. 2007. Exogenous nitric oxide protect cucumber roots against oxidative stress induced by salt stress. Plant Physiology and Biochemistry. 45, 542-550.

Srivastava, S., Dubey, R.S. 2012. Nitric oxide alleviates manganese toxicity by preventing oxidative stress in excised rice leaves. Acta Physiol. Plant, 34, 819-825.

Tariq, A., Masroor, A.K.M., Teixeira da Silva, J.A., Mohd, I., M. Naeem, Moinuddin. 2011. Role of salicylic acid in promoting salt stress tolerance and enhanced artemisinin production in artemisia annua L. Journal of plant growth regulation. 30, 425-435

Vaidyanathan, H., Sivakumar, P., Chakrabarty, R., Thomas, G. 2003. Scavenging of reactive oxygen species in NaCl-stressed rice (Oryza sativa L.) differential response in salt-tolerant and sensitive varieties. Plant Science. 165, 1411-1418.

Xiong, J., Fu, G., Tao, L., Zhu, C. 2010. Roles of nitric oxide in alleviating heavy metal toxicity in plants. Archives of biochemistry and biophysics. 497, 13-20.

Yamasaki, S., Dillenburg, L.C. 1999. Measurements of leaf relative water content in Araucaria angustifolia. R. Bras. Fisiol. Veg. 11, 69-75.

Zottini, M., Formentin E., Scattolin M., Carimi F., Schiavo F.L., Terzi M. 2002. Nitric oxide affects plant mitochondrial functionality in vivo. Febs letters. 515, 75-78. 
Zhang, X.W., Dong, Y.J., Qiu, X.K., Hu, G.Q., Wang, Y.H., Wang, Q.H. 2012. Exogenous nitric oxide alleviates iron-deficiency chlorosis in peanut growing on calcareous soil. Plant, soil and Environment. 58, 111-120.
Zeng, C.L., Liu, L., Wang, B.R., Wu, X.M., Zhou, Y. 2011. Physiological effects of exogenous nitric oxide on Brassica juncea seedlings under $\mathrm{NaCl}$ stress. Biologia Plantarum. 55, 345-348. 